\begin{tabular}{|l|l|l||}
\hline \multicolumn{2}{|c|}{ PublisherInfo } \\
\hline \hline PublisherName & $:$ & BioMed Central \\
\hline \hline PublisherLocation & $:$ & London \\
\hline \hline PublisherImprintName & $:$ & BioMed Central \\
\hline \hline
\end{tabular}

\title{
ErbB-receptors in antiestrogen resistance
}

\begin{tabular}{||l|l|l||}
\hline \multicolumn{2}{|c||}{ ArticleInfo } \\
\hline \hline ArticleID & $:$ & 3691 \\
\hline \hline ArticleDOI & $:$ & $10.1186 /$ bcr-2000-66654 \\
\hline \hline ArticleCitationID & $:$ & 66654 \\
\hline \hline ArticleSequenceNumber & $:$ & 57 \\
\hline \hline ArticleCategory & $:$ & Paper Report \\
\hline ArticleFirstPage & $:$ & 1 \\
\hline \hline ArticleLastPage & $:$ & 4 \\
\hline \hline & $:$ & RegistrationDate : 2000-2-8 \\
ArticleHistory & $:$ & OnlineDate \\
\hline \hline ArticleCopyright $2000-2-8$ \\
\hline \hline ArticleGrants & $:$ & Current Science Ltd2000 \\
\hline \hline ArticleContext & $:$ & \\
\hline \hline
\end{tabular}




\section{Keywords}

Antiestrogens, EGFR, HER-2/neu, heregulin-ÃŽÂA1, resistance

\section{Introduction}

Current members of the type I growth factor receptor family include EGFR (HER-1, ErbB-1), HER-2/neu (ErbB-2), ErbB-3 and ErbB-4. Although generally expressed at low levels in breast epithelial cells, EGFR is often overexpressed in breast cancers and is associated with poor prognosis as EGFR positive tumors do not respond to endocrine therapy. Similarly, HER-2/neu overexpression is associated with endocrine resistance and decreased survival. Although less is known about the newer members, ErbB-3 and -4, they also have been implicated in breast cancer.

\section{Aims}

To investigate whether changes in expression of members of the type I growth factor receptor family were associated with antiestrogen resistance.

\section{Comments}

Resistance to antiestrogens in breast cancer remains a considerable clinical dilemma. A more thorough understanding of the mechanisms associated with resistance is necessary to develop alternative treatment regimens. From this work, it would appear that acquired antiestrogen resistance is not due to alterations in expression of the ErbB-2 receptor family, therefore receptor levels alone cannot predict antiestrogen resistance. However, as ligand bound receptorcan inhibit the anti-proliferative effects of antiestrogens, it is important to understand how these signalling pathways may interact.

\section{Methods}


A panel of cell lines including wild type MCF-7 and 10 antiestrogen-resistant variants previously developed and characterised by the group were used. Profiles of type I growth factor receptors in these cell lines were obtained by RT-PCR, northern, Southern and western blotting. The effects of estrogens and antiestrogens on expression of these receptors was also investigated.

\section{Results}

No gene amplification of HER-2/neu was observed in antiestrogen resistant compared with wild type MCF-7 cells. Similarly, no major changes in basal mRNA levels of EGFR, HER-2/neu, ErbB-3 and -4 were seen. Hormonal regulation of HER-2/neu was virtually identical in the sensitive and resistant cell lines. In general, estrogens reduced HER-2/neu levels (both protein and mRNA) while with antiestrogens these levels were increased. Addition of an antibody against HER-2/neu (Herceptin) had no effect on cell proliferation in wild type or resistant cells, nor was there an enhanced anti-proliferative effect of Herceptin and antiestrogen when added in combination. Stable constructs of MCF-7 overexpressing either HER-2/neu or HER-2/neu plus ErB-3, showed that overexpression of these receptors did not confer resistance. However, addition of heregulin- $\beta 1$ significantly reduced the growth inhibition of these transfected cells and also abolished the inhibitory effect of antiestrogen on the HER-2/neu plus Erb-3 co-transfectant.

\section{Discussion}

The results indicate that HER-2/neu receptor is not directly involved in acquisition of antiestrogen resistance in vitro. However, when the receptor is activated by heterodimerisation with ligand (available through paracrine or autocrine routes) bound ErbB-3 or -4 , this may impact on the antiestrogen signalling pathway, resulting in resistance.

\section{References}


1. Larsen SS, Egeblad M, Jaattela M, Lykkesfeldt AE: Acquired antiestrogen resistance in MCF-7 human breast cancer sublines is not accomplished by altered expression of receptors in the ErbB-family. Breast Cancer Res Treat. 2000, 58: 41-56. 